\title{
Broad-Scope Rh-Catalyzed Inverse-Sonogashira Reaction Directed by Weakly Coordinating Groups
}

\author{
Eric Tan, ${ }^{\dagger, \S}$ Ophélie Quinonero, ${ }^{\dagger, \S \odot}$ M. Elena de Orbe, ${ }^{\dagger}$ and Antonio M. Echavarren ${ }^{*}, \dagger, \ddagger(0)$ \\ 'Institute of Chemical Research of Catalonia (ICIQ), Barcelona Institute of Science and Technology, Av. Països Catalans 16, 43007 \\ Tarragona, Spain \\ ‡Departament de Química Orgànica i Analítica, Universitat Rovira i Virgili, C/Marcel·lí Domingo s/n, 43007 Tarragona, Spain
}

Supporting Information

ABSTRACT: We report the alkynylation of $\mathrm{C}\left(\mathrm{sp}^{2}\right)-\mathrm{H}$ bonds with bromoalkynes (inverse-Sonogashira reaction) directed by synthetically useful ester, ketone, and ether groups under rhodium catalysis. Other less common directing groups such as amine, thioether, sulfoxide, sulfone, phenol ester, and carbamate are also suitable directing groups. Mechanistic studies indicate that the reaction proceeds by a turnoverlimiting $\mathrm{C}-\mathrm{H}$ activation step via an electrophilic-type substitution.

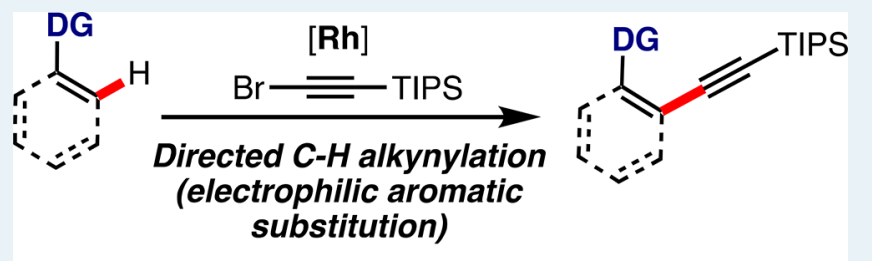

DG $=\mathrm{CH}_{2} \mathrm{OMe}$ (17 examples), $\mathrm{CO}_{2} \mathrm{R}$ (31 examples), COR (20 examples)

KEYWORDS: alkynylation, rhodium catalysis, C-H functionalization, inverse Sonogashira, metallacycle, Hammett correlation, DFT

\section{INTRODUCTION}

Alkynes are among the most versatile functional groups ${ }^{1}$ and are widely present in natural products, ${ }^{2}$ drugs, ${ }^{3}$ and organic materials. ${ }^{4}$ The chemistry of alkynes has gained particular momentum in recent years by the discovery of a wide variety of catalytic transformations triggered by gold(I), platinum(II), and other alkynophilic Lewis acids. ${ }^{5}$ Therefore, the development of methods for the introduction of alkyne groups onto organic molecules is of high importance. To this end, the Sonogashira coupling reaction is the most general method for the formation of $\mathrm{C}(\mathrm{sp})-\mathrm{C}\left(\mathrm{sp}^{2}\right)$ bonds from aryl or alkenyl (pseudo)halides and terminal alkynes. ${ }^{6}$

The main limitation of the Sonogashira coupling reaction resides in the synthetic availability of the required (pseudo)halides. An alternative approach that is better suited for the late-stage functionalization of complex molecules involves the alkynylation of $\mathrm{C}\left(\mathrm{sp}^{2}\right)-\mathrm{H}$ bonds with terminal alkynes or activated acetylenes such as ethynylbenziodoxolone (EBX) reagents or haloalkynes using transition-metal catalysts. ${ }^{7}$ Often named inverse-Sonogashira coupling, this methodology relies on the reactivity of electronically activated (hetero)arenes ${ }^{8}$ or on a chelating group to assist a $\mathrm{C}-\mathrm{H}$ activation process. ${ }^{9}$ The former strategy is restricted to aromatic $\mathrm{C}\left(\mathrm{sp}^{2}\right)-\mathrm{H}$ bonds, which need in addition to be acidic or electron-rich enough to undergo deprotonation or a Friedel-Crafts type reaction. The latter has been achieved for both arenes and alkenes ${ }^{9 b}$ with a variety of directing groups, typically amides or nitrogen coordinating groups such as heterocycles or imine derivatives (oxime, nitrone, azomethine). ${ }^{9 \mathrm{c}}$ The applicability of this strategy in multistep synthesis is however limited, as in most cases the directing groups need to be installed and/or removed. Therefore, to render this approach useful, the development of new protocols using instead widely used functional groups serving as synthetic handles is highly desirable. ${ }^{10}$

Toward this goal, we recently reported a general perialkynylation of naphthols using ruthenium catalysis. ${ }^{11}$ Benzoic acids can also be alkynylated at the ortho position, ${ }^{11,12}$ although the use of other versatile $\mathrm{O}$ functionalities ${ }^{13,14}$ as directing groups is still limited, mainly due to the challenging formation of a weakly coordinated metallacyclic intermediate. ${ }^{15}$ In particular, despite intense efforts in the field of catalytic $\mathrm{C}\left(\mathrm{sp}^{2}\right)-\mathrm{H}$ functionalization, only two examples of the use of benzyl ether as a directing group have been reported in the context of $\mathrm{C}-\mathrm{H}$ borylation.

Here, we report the use of synthetically useful ether, ester, and ketone as directing groups for the direct alkynylation of $\mathrm{C}\left(\mathrm{sp}^{2}\right)-\mathrm{H}$ bonds with bromoalkynes under rhodium catalysis (Scheme 1). ${ }^{17}$ We also demonstrate for the first time that amine $^{18}$ thioether, $^{19}$ sulfoxide, ${ }^{20}$ sulfone, ${ }^{21}$ carbamate, ${ }^{22}$ and phenol esters ${ }^{23}$ are suitable directing groups in this transformation. Furthermore, our experimental and theoretical mechanistic study shows that this $\mathrm{Rh}$-catalyzed alkynylation occurs by a turnover-determining $\mathrm{C}-\mathrm{H}$ activation in which a five-membered ring metallacycle is formed by an electrophilic aromatic substitution type process.

\section{RESULTS AND DISCUSSION}

Reaction Scope. Our studies began by evaluating the reactions of TIPS-protected bromoacetylene (1) with ethyl benzoate (2a) and benzyl methyl ether (4a). We discovered that a combination of $\left[\mathrm{Cp}^{*} \mathrm{RhCl}_{2}\right]_{2}(2.5 \mathrm{~mol} \%), \mathrm{AgSbF}_{6}(20$

Received: December 20, 2017

Revised: January 23, 2018

Published: January 29, 2018 
Scheme 1. C $\left(\mathrm{sp}^{2}\right)-\mathrm{H}$ Alkynylation with Bromoalkynes Directed by a Broad Range of Coordinating Groups under Rhodium Catalysis

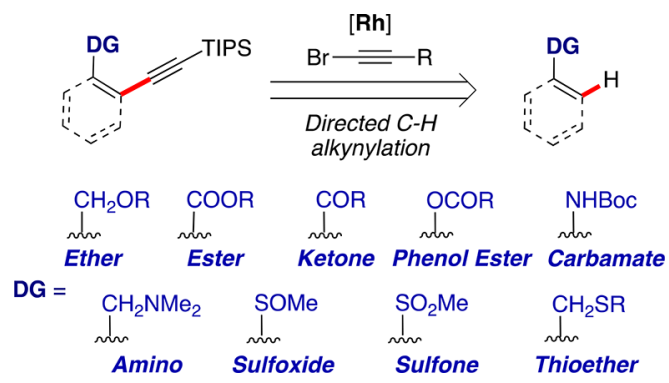

mol \%), $\mathrm{Ag}_{2} \mathrm{CO}_{3}$ (1 equiv), and $\mathrm{LiOAc}(20 \mathrm{~mol} \%)$ in 1,2dichloroethane (DCE) at $45{ }^{\circ} \mathrm{C}$ provided 3a in $69 \%$ yield (Table 1, entry 1). Control experiments showed the essential

Table 1. Rh-Catalyzed o-C-H Alkynylation of Ethyl Benzoate and Benzyl Methyl Ether: Optimization Conditions $^{24}$

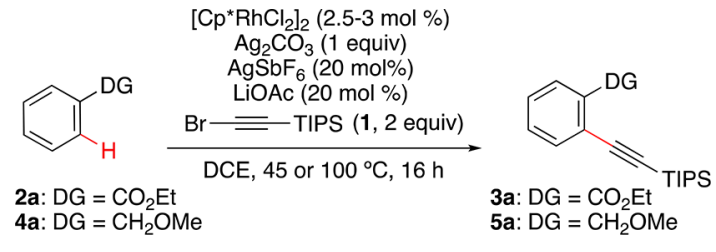

\begin{tabular}{|c|c|c|c|}
\hline entry & DG & variation from the "standard conditions" $a$ & yield $(\%)^{b}$ \\
\hline 1 & ester & none & $58-69$ \\
\hline 2 & ester & at $25^{\circ} \mathrm{C}^{c}$ & 35 \\
\hline 3 & ester & at $65^{\circ} \mathrm{C}^{c}$ & 16 \\
\hline 4 & ester & with $\mathrm{Ag}_{2} \mathrm{CO}_{3}$ ( 0.5 equiv $)^{d}$ & 41 \\
\hline 5 & ester & with $\mathrm{K}_{2} \mathrm{CO}_{3}$ (1 equiv) ${ }^{d}$ & 5 \\
\hline 6 & ester & in dichloromethane $e^{e}$ & $8-14$ \\
\hline 7 & ester & in toluene $e^{e}$ & 0 \\
\hline 8 & ester & in $t-\mathrm{AmOH}^{e}$ & 0 \\
\hline 9 & ester & in $\mathrm{Et}_{2} \mathrm{O}^{e}$ & 4 \\
\hline 10 & ester & in $\mathrm{EtOAc}^{e}$ & 18 \\
\hline 11 & ester & in $\mathrm{MeOH}^{e}$ & 0 \\
\hline 12 & ether & none & 0 \\
\hline 13 & ether & at $100{ }^{\circ} \mathrm{C}^{c}$ & $50-64$ \\
\hline 14 & ether & without $\left[\mathrm{Cp}^{*} \mathrm{RhCl}_{2}\right]_{2}$ & 0 \\
\hline 15 & ether & without $\mathrm{Ag}_{2} \mathrm{CO}_{3}$ & 0 \\
\hline 16 & ether & without $\mathrm{LiOAc}$ & 0 \\
\hline 17 & ether & without $\mathrm{AgSbF}_{6}$ & 0 \\
\hline 18 & ether & with $\mathrm{AgOAc}(1.2 \text { equiv })^{f}$ & $<1.5$ \\
\hline 19 & ether & $\mathrm{AgOAc}(1$ equiv $)+\mathrm{Ag}_{2} \mathrm{CO}_{3}(0.2 \text { equiv })^{g}$ & 12 \\
\hline 20 & ether & in toluene $e^{e}$ & 0 \\
\hline 21 & ether & in tert-amOH ${ }^{e}$ & 0 \\
\hline 22 & ether & in 1,4 -dioxane $e^{e}$ & 0 \\
\hline 23 & ether & with TIPS-acetylene ${ }^{h}$ & 0 \\
\hline 24 & ether & with $\left[\mathrm{Cp} * \mathrm{IrCl}_{2}\right]_{2}^{i}$ & 0 \\
\hline 25 & ether & with $\mathrm{Pd}(\mathrm{OAc})_{2}^{i}$ & 0 \\
\hline 26 & ether & with $\left[\mathrm{RuCl}_{2}(p \text {-cymene })\right]_{2}{ }^{i}$ & $<3$ \\
\hline
\end{tabular}

${ }^{a}$ Standard reaction conditions: $\mathbf{2 a}$ or $\mathbf{4 a}(0.2 \mathrm{mmol}), \mathbf{1}$ (2 equiv), $\left[\mathrm{Cp}^{*} \mathrm{RhCl}_{2}\right]_{2}(2.5 \mathrm{~mol} \%$ for DG $=$ ester, $3 \mathrm{~mol} \%$ for DG = ether $)$, $\mathrm{Ag}_{2} \mathrm{CO}_{3}$ (1 equiv), $\mathrm{AgSbF}_{6}$ (0.2 equiv), $\mathrm{LiOAc}$ (0.2 equiv), DCE, $16 \mathrm{~h}$, $45{ }^{\circ} \mathrm{C}$. ${ }^{b}$ Yield of the monoalkynylated product determined by ${ }^{1} \mathrm{H}$ NMR using bromomesitylene as internal standard. ${ }^{c}$ Instead of $45^{\circ} \mathrm{C}$. ${ }^{d}$ Instead of $\mathrm{Ag}_{2} \mathrm{CO}_{3}$ (1 equiv). ${ }^{e}$ Instead of DCE. ${ }^{f}$ Instead of $\mathrm{Ag}_{2} \mathrm{CO}_{3}$ and LiOAc. ${ }^{g}$ Without LiOAc. ${ }^{h}$ Instead of $1 .{ }^{i}$ Instead of $\left[\mathrm{Cp}^{*} \mathrm{RhCl}_{2}\right]_{2}$. role of all reaction components (Table 1, entries 2-11). Thus, lower yields of $3 \mathbf{a}$ were obtained at temperatures lower or higher than $45{ }^{\circ} \mathrm{C}$ (Table 1, entries 2 and 3). Similar results were obtained by decreasing the amount of $\mathrm{Ag}_{2} \mathrm{CO}_{3}$ to 0.5 equiv or replacing this silver salt by $\mathrm{K}_{2} \mathrm{CO}_{3}$ (Table 1 , entries 4 and 5). Solvents different from DCE led to poor results (Table 1 , entries 6-11). The use of other bromoalkynes, such as (bromoethynyl)benzene and 1-bromooctyne, led to no conversion. ${ }^{2}$

Although treatment of benzyl methyl ether (4a) with bromoacetylene 1 under essentially the same conditions did not lead to the product of alkynylation (Table 1, entry 12), simply increasing the temperature to $100{ }^{\circ} \mathrm{C}$ led to $5 \mathrm{a}$ in $64 \%$ yield (Table 1, entry 13). Using ethynyltriisopropylsilane instead of 1 did not afford 5a (Table 1, entry 23). Replacing $\left[\mathrm{Cp}^{*} \mathrm{RhCl}_{2}\right]_{2}$ with other metal catalysts typically used in $\mathrm{C}-\mathrm{H}$ functionalization did not lead to alkynylated product (Table 1 , entries 24-26). The alternative hydroxy-directed alkynylation of primary, secondary, or tertiary benzyl alcohol led to oxidation, decomposition, or unproductive reaction.

Different alkyl benzoates $\mathbf{2} \mathbf{a}-\mathbf{d}$ could be ortho-alkynylated, with ethyl benzoate $\mathbf{2 a}$ giving the highest yield (Scheme 2). Electron-donating alkyl or methoxy groups and electronwithdrawing substituents such as $\mathrm{NO}_{2}, \mathrm{CF}_{3}$, and different

Scheme 2. Rh-Catalyzed o-C-H Alkynylation of Alkyl Benzoates $^{a}$

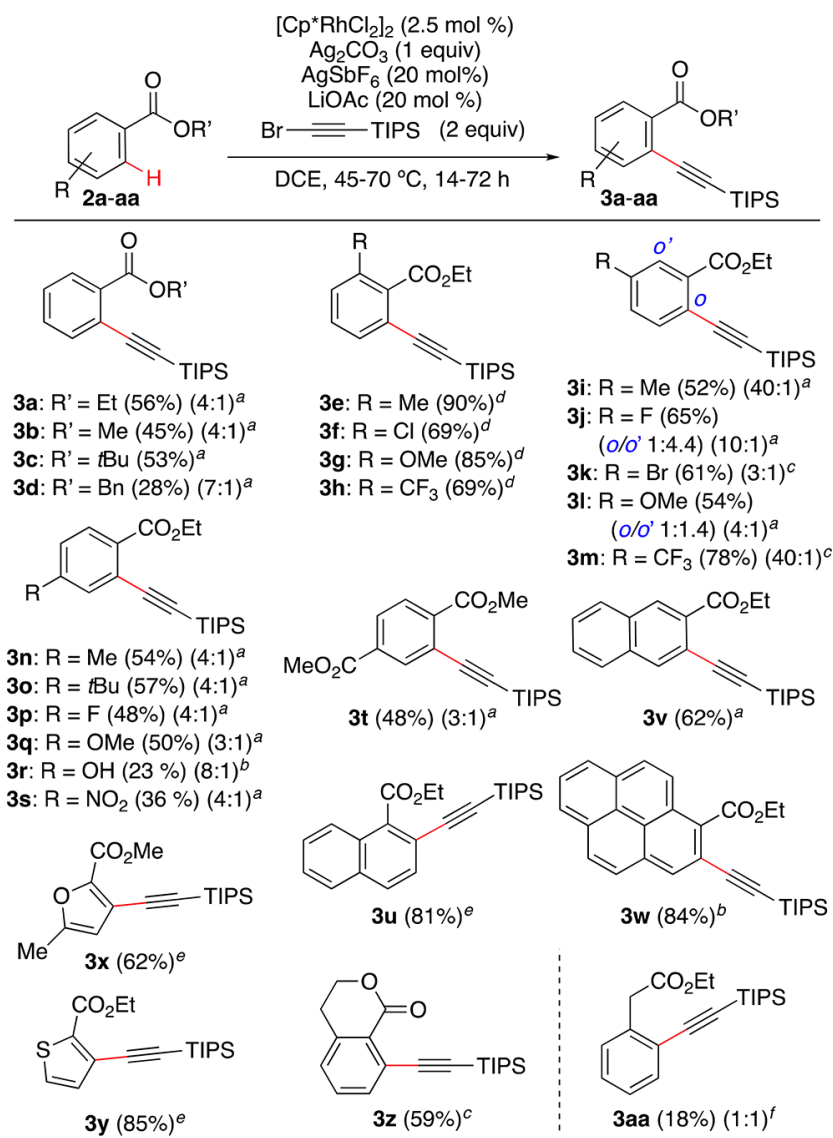

${ }^{a}$ Legend to conditions: (a) $45^{\circ} \mathrm{C}, 16-24 \mathrm{~h}$; (b) $45^{\circ} \mathrm{C}, 48 \mathrm{~h}$; (c) 45 ${ }^{\circ} \mathrm{C}, 72 \mathrm{~h}$; (d) $60{ }^{\circ} \mathrm{C}, 48 \mathrm{~h}$; (e) $70{ }^{\circ} \mathrm{C}, 24-72 \mathrm{~h}$; (f) $90{ }^{\circ} \mathrm{C}, 72 \mathrm{~h}(0.2$ mmol scale). Yields of isolated monoalkynylated products are shown. In cases in which diakynylated products were also formed, mono- vs dialkynylation selectivity is shown in parentheses. 
halides at the ortho, meta, and para positions were well tolerated, affording alkynylated products $3 \mathbf{e}-\mathbf{w}$ in $23-90 \%$ yield. In the case of meta-substituted substrates $\mathbf{2} \mathbf{i}, \mathbf{k}, \mathbf{m}$, the alkynylation occurred at the least sterically hindered site. However, fluoro and methoxy derivatives $2 \mathrm{j}, \mathbf{l}$ favor formation of the 1,2,3-trisubstituted compounds $\mathbf{3 j} \mathbf{j} \mathbf{l}$, respectively.

The alkynylation of ethyl 1-naphthoate (2u) and ethyl pyrene-1-carboxylate $(2 \mathbf{w})$ does not take place at the peri position, leading instead to ortho-fuctionalized products $3 \mathbf{u}, \mathbf{w}$, respectively. Reaction of ethyl 2-naphthoate (2v) afforded exclusively the product of alkynylation at C-3 (3v). Furan and thiophene esters were also alkynylated to give $3 \mathbf{x}(62 \%)$ and $3 y$ (85\%), respectively. The carbonyl group of isochroman-1-one is also an effective directing group, affording $3 z$ in $59 \%$ yield. On the other hand, the alkynylation of ethyl phenylacetate required heating at $90{ }^{\circ} \mathrm{C}$ and was less efficient, leading to 3aa in $18 \%$ yield along with an equivalent amount of the dialkynylated product.

Whereas the alkynylation of 4 a leads to 5 a in $64 \%$ yield, substrates $\mathbf{4 b}-\mathbf{d}$ with bulkier alkyl or silyl groups failed to give the expected products (Scheme 3). Similarly, MOM-protected

Scheme 3. Rh-Catalyzed o-C-H Alkynylation of Benzyl Ethers ${ }^{a}$

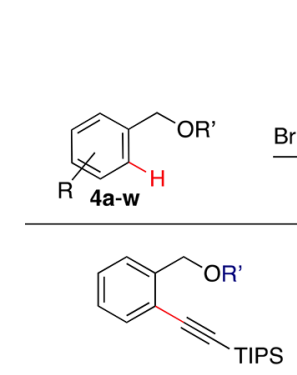

5a: $R^{\prime}=$ Me $(64 \%)$

5b: R' = $\mathrm{tBu}(0 \%)$

5c: $R^{\prime}=B n(0 \%)$

5d: R' $=$ TMS $(0 \%)$

5e: $R^{\prime}=\operatorname{MOM}(0 \%)$

5f: $R^{\prime}=A c(0 \%)$

5g: R' $=$ Piv $(0 \%)$

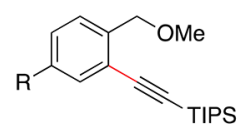

5q: $R=F(58 \%)$

5r: $\mathrm{R}=\mathrm{Cl}(48 \%)(1.4: 1)$

5s: $R=\operatorname{Br}(55 \%)(2: 1)$

5t: $\mathbf{R}=\mid(32 \%)$

5u: $R=\mathrm{CF}_{3}(45 \%)(3: 1)$ 5p: $R=\operatorname{Pr}(40 \%)$
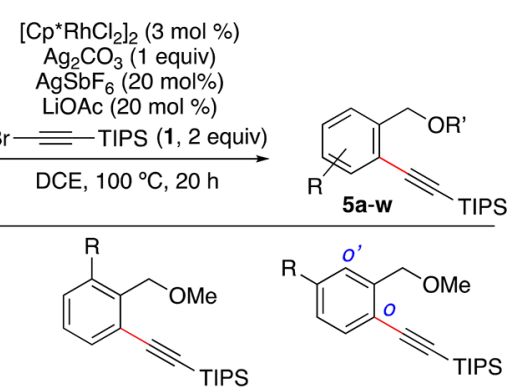

5h: $R=F(67 \%)$

5i: $\mathrm{R}=\mathrm{Cl}(67 \%)$

5j: $\mathrm{R}=\mathrm{Br}(71 \%)$

$5 \mathbf{k}: \mathbf{R}=I(55 \%)$

5I: $\mathrm{R}=\mathrm{CF}_{3}(59 \%)$

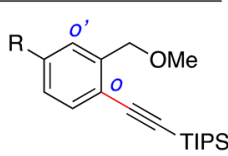

$5 \mathrm{~m}: \mathrm{R}=\mathrm{F}(40 \%)$

$\left(o / o^{\prime} 1: 1.5\right)(3: 1)$

5n: $\mathrm{R}=\mathrm{Cl}(55 \%)$

5o: $\mathrm{R}=\mathrm{CF}_{3}(70 \%)$
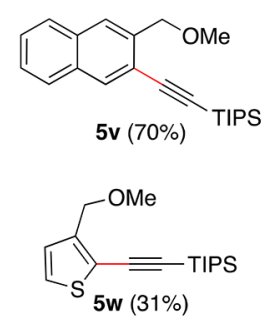

${ }^{a}$ Yields of isolated monoalkynylated products are shown. In cases in which diakynylated products were also formed, mono- vs dialkynylation selectivity is shown in parentheses.

benzyl alcohol $\mathbf{4 e}$ and esters $\mathbf{4 f}, \mathbf{g}$ were unreactive substrates. On the other hand, methyl benzyl ethers bearing diverse substituents at the ortho, meta, or para positions such as $i$-Pr, $\mathrm{CF}_{3}$, fluoro, chloro, bromo, and iodo led to o-alkynylated products $\mathbf{5 h}-\mathbf{u}$ in $32-71 \%$ yields. As observed for the benzoates, the alkynylation of meta-substituted substrates 4n,o occurred at the least sterically hindered site, whereas fluoro derivative $4 \mathrm{~m}$ led to a mixture of ortho-alkynylated derivatives $\mathbf{5 m}$, favoring the formation of the 1,2,3-trisubstituted product. Again, the alkynylation of naphthyl derivative $4 \mathbf{v}$ takes place at C-3 to form $5 v$ in $70 \%$ yield. The reaction of thiophene $4 w$ provided $5 w$, the product of C-2 alkynylation, which was isolated in $31 \%$ yield.

Under conditions similar to those used for the reaction of the ester derivatives, a wide variety of aryl ketones $6 a-p$ could be alkynylated in a general manner to give $7 \mathbf{a}-\mathbf{p}$ in good to excellent yield (Scheme 4). Bis(alkynylated)acetophenone $7 \mathbf{k}$

\section{Scheme 4. Rh-Catalyzed o-C-H Alkynylation of Aryl} Ketones $^{a}$

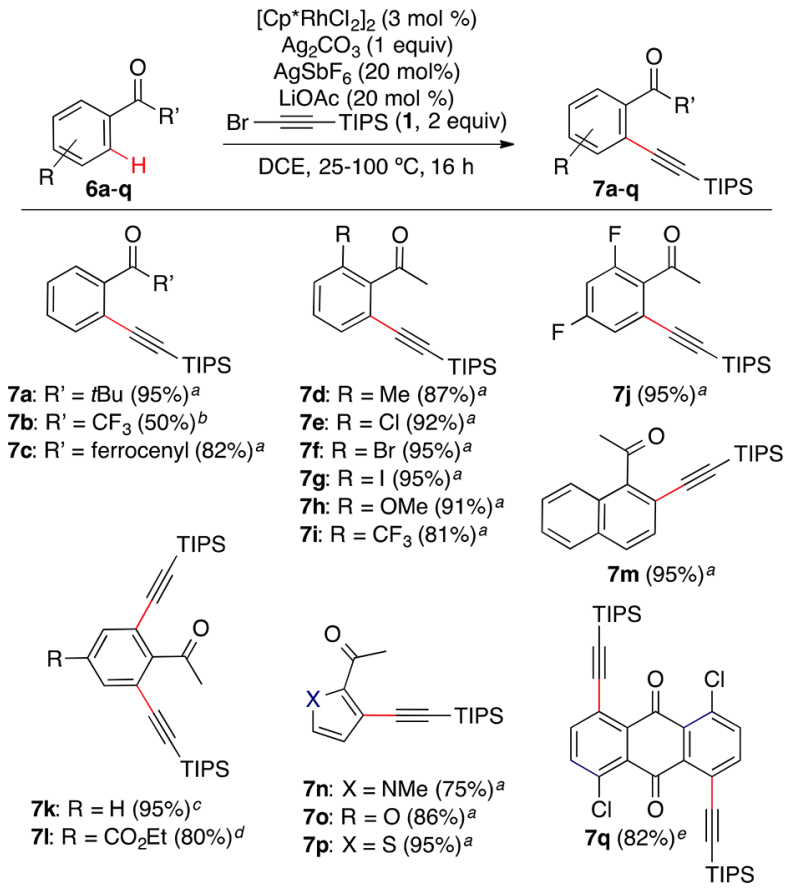

${ }^{a}$ Legend to conditions: (a) $45{ }^{\circ} \mathrm{C}$, (1 equiv 1); (b) $90{ }^{\circ} \mathrm{C}$, (1 equiv 1); (c) $25{ }^{\circ} \mathrm{C}$, (2 equiv 1); (d) $45^{\circ} \mathrm{C}$, (2 equiv 1); (e) $100{ }^{\circ} \mathrm{C}$, (2 equiv 1).

was obtained in quantitative yield from acetophenone at room temperature, while bulkier alkyl substituents allowed a monoselective alkynylation, affording products $7 \mathbf{a}-\mathrm{c}$ in $50-$ 95\% yield. Diverse substituents at the ortho position of acetophenone were well tolerated to give products $7 \mathbf{d}-\mathbf{i}$ in $81-$ $95 \%$ yield. 2-Acetyl derivatives $N$-methylpyrrole (6n), furan (6o), and thiophene (6p) were alkynylated at C-3 in $75-95 \%$ yield. The double alkynylation of 1,5-dichloroanthraquinone (6q) proceeded at $100{ }^{\circ} \mathrm{C}$ to give dialkynylated product $7 \mathbf{q}$ in $82 \%$ yield.

As an example of late-stage functionalization of a pharmaceutical compound, fenofibrate (6r) was alkynylated in $35 \%$ yield for the major product (Scheme 5).

Scheme 5. Late-Stage Alkynylation of Fenofibrate ${ }^{a}$<smiles></smiles>

${ }^{a}$ Standard conditions for the Rh-catalyzed reaction using 2 equiv of bromoalkyne, at $50{ }^{\circ} \mathrm{C}, 14 \mathrm{~h}$. 
Stereocontrolled synthesis of conjugated enynes or acyclic tri- and tetrasubstituted alkenes is a longstanding challenge in organic chemistry. ${ }^{25} \mathrm{We}$ were pleased to find that the alkynylation of vinyl $\mathrm{C}-\mathrm{H}$ bonds of $\alpha, \beta$-unsaturated esters $\mathbf{8 a}-\mathbf{e}$ and ketones $\mathbf{8 f}, \mathbf{g}$ proceeded under the standard conditions at $45-85{ }^{\circ} \mathrm{C}$ to afford a series of $Z$-configured 1,3 -enynes $9 \mathbf{a}-\mathbf{g}$ in $44-84 \%$ yield, with total control of the stereoselectivity (Scheme 6).

Scheme 6. Alkynylation of Vinyl C-H Bonds ${ }^{a}$

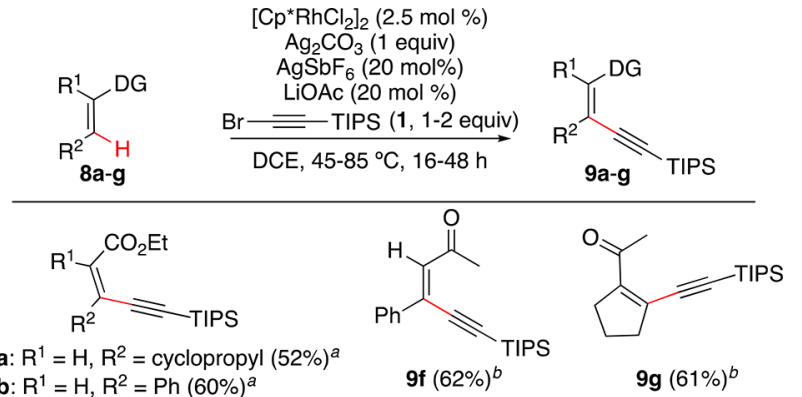

9b: $R^{1}=H, R^{2}=P h(60 \%)^{a}$

9c: $\mathrm{R}^{1}=\mathrm{H}, \mathrm{R}^{2}=p-\mathrm{EtOC}_{6} \mathrm{H}_{4}(44 \%)^{a}$

9d: $\mathrm{R}^{1}=\mathrm{H}, \mathrm{R}^{2}=p-\mathrm{BrC}_{6} \mathrm{H}_{4}(66 \%)^{a}$

9e: $R^{1}=P h, R^{2}=P h(84 \%)^{a}$

${ }^{a}$ Legend to conditions: (a) $85{ }^{\circ} \mathrm{C} 48 \mathrm{~h},\left(2\right.$ equiv 1); (b) $45^{\circ} \mathrm{C}, 16 \mathrm{~h}(1$ equiv 1).

Other Directing Groups. With slight modification of the reaction conditions, we discovered that other functional groups are viable chelating groups (Scheme 7 ). As rare examples of the

Scheme 7. Rhodium-Catalyzed $\mathrm{C}\left(\mathbf{s p}^{2}\right)-\mathrm{H}$ Alkynylation with Other Directing Groups ${ }^{a}$

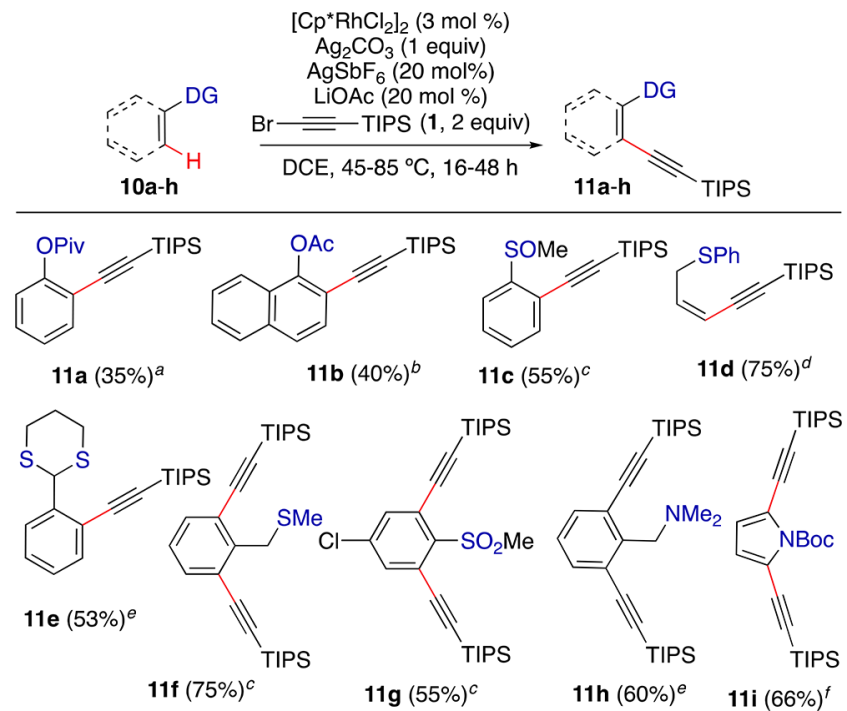

${ }^{a}$ Legend to conditions: (a) $90{ }^{\circ} \mathrm{C}, 72 \mathrm{~h}$; (b) $70{ }^{\circ} \mathrm{C}, 24 \mathrm{~h}$; (c) $100{ }^{\circ} \mathrm{C}$, $16 \mathrm{~h}$; (d) $50{ }^{\circ} \mathrm{C}$, (1 equiv 1), $16 \mathrm{~h}$; (e) $90{ }^{\circ} \mathrm{C}, 16 \mathrm{~h}$; (f) $45^{\circ} \mathrm{C}, 16 \mathrm{~h}$.

use of a simple phenol ester as a directing group, ${ }^{23}$ the ortho alkynylation of phenol pivalate (10a) and 1-naphthol acetate (10b) led to $11 \mathbf{a}, \mathbf{b}$ in moderate yields. Although they are considered to bind too tightly to metals to be involved in catalytic processes, strongly coordinating groups could also be used under similar conditions. Thus, the reaction proceeds on substrates bearing sulfoxide, thioether, thioacetal, sulfone, and tertiary amine functional groups, giving products $11 \mathrm{c}-\mathbf{h}$ in $53-$ $75 \%$ yield. Boc-protected pyrrole $10 \mathrm{i}$ could also be dialkynylated to give product $11 \mathrm{i}$ in $66 \%$ yield.

Mechanistic Studies. Several experiments were carried out in order to shed light on the reaction mechanism. First, the C$\mathrm{H}$ functionalization step was found to be irreversible according to the reaction of $2 \mathrm{a}-\boldsymbol{d}_{5}$ in the presence of water and in the absence of bromoalkyne $\mathbf{1}$ (Scheme 8i). The intermolecular

\section{Scheme 8. D/H Exchange, Kinetic, and Competition} Experiments ${ }^{a, 24}$

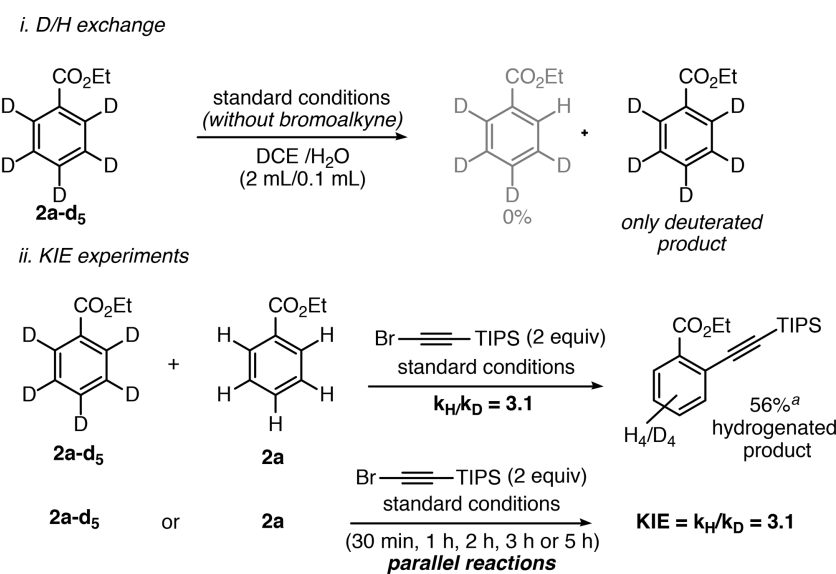

iii. Competition experiments

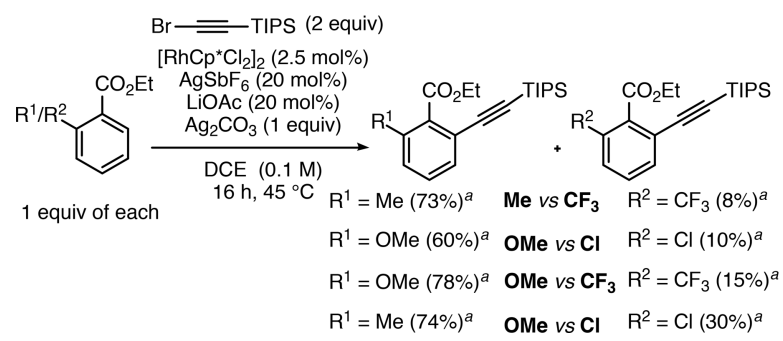

${ }^{a}$ Yield of the monoalkynylated product determined by ${ }^{1} \mathrm{H}$ NMR using bromomesitylene as internal standard.

and parallel competition experiments between deuterated and hydrogenated labeled substrates (Scheme 8ii) showed the same kinetic isotope effect $(\mathrm{KIE}=3.1)$ in both cases, indicating that the $\mathrm{C}-\mathrm{H}$ bond cleavage probably occurs in the ratedetermining step of the catalytic cycle, ${ }^{26}$ which is consistent with related rhodium-catalyzed $\mathrm{C}-\mathrm{H}$ functionalizations. ${ }^{27}$ Finally, the intermolecular competition between electron-rich and electron-poor substrates (Scheme 8iii) suggests that substrates bearing electron-donating groups ( $\mathrm{Me}$ or $\mathrm{MeO}$ ) at the meta position of the $\mathrm{C}-\mathrm{H}$ functionalization site are more reactive. This result indicates that the $\mathrm{C}-\mathrm{H}$ functionalization step might occur through an electrophilic aromatic substitution type mechanism. ${ }^{12 \mathrm{~b}, 28}$

A Hammett correlation was found $\left(R^{2}=0.99\right.$ using $\left.\sigma_{\mathrm{p}}^{+}\right)$for meta-substituted substrates (Figure 1). ${ }^{29}$ A negative $\rho$ value also suggests that electron density decreases at the aryl ring in the product-determining step, which is in accordance with a C$\mathrm{H}$ functionalization step occurring through an electrophilic aromatic substitution type mechanism.

To get a deeper insight into the reaction mechanism, we performed DFT calculations (Scheme 9) ${ }^{30,31}$ According to our studies, the $\mathrm{C}-\mathrm{H}$ functionalization of methyl benzoate $(\mathbf{2 b})$ proceeds from Intla by the intramolecular assistance of the 


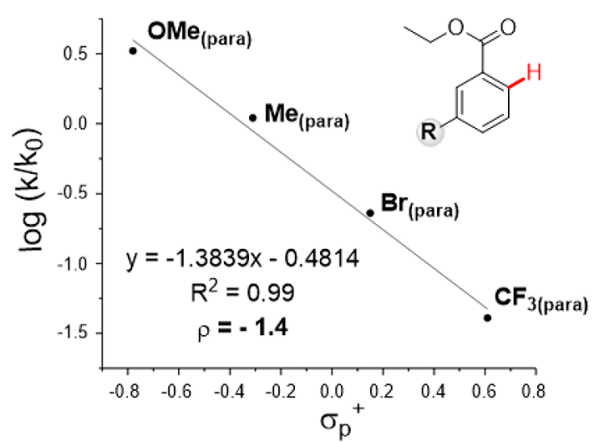

Figure 1. Hammett plot for the reaction of meta-substituted benzoates. $^{24}$

Scheme 9. Proposed Mechanism of the Rh-Catalyzed $\mathrm{C}\left(\mathrm{sp}^{2}\right)-\mathrm{H}$ Alkynylation on the Basis of DFT Calculations ${ }^{a}$

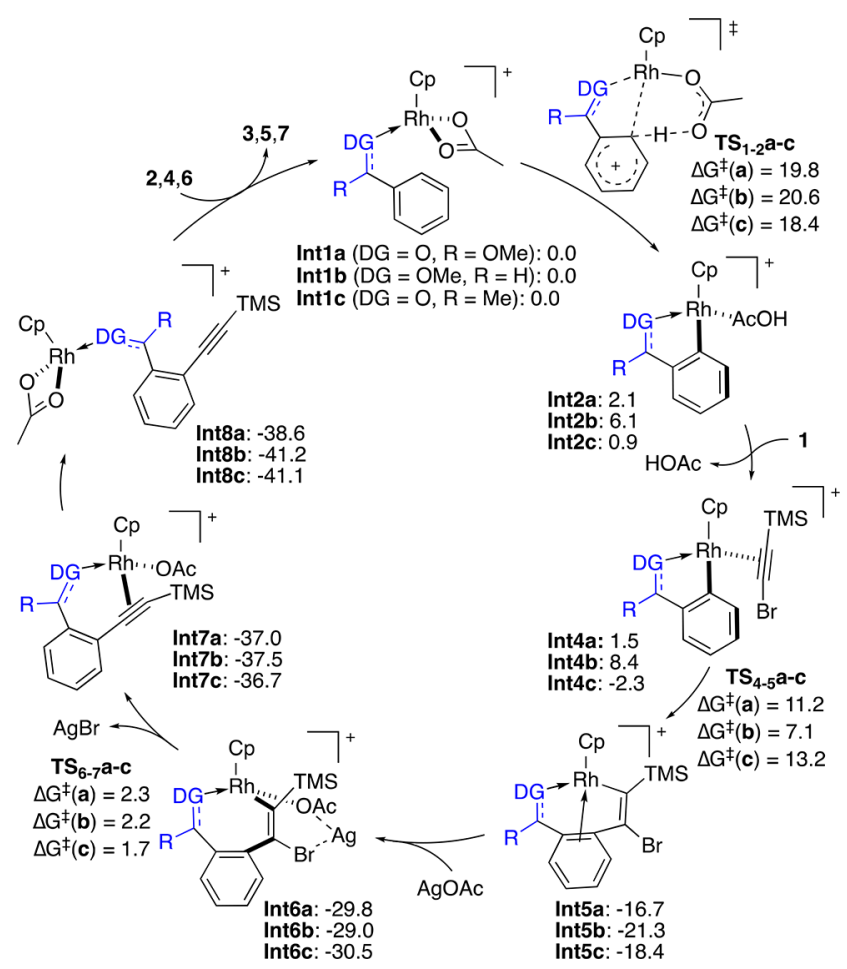

${ }^{a}$ Free energies in $\mathrm{kcal} / \mathrm{mol}$.

acetate ligand through the six-membered cyclic transition state $\mathbf{T S}_{1-2} \mathbf{a}\left(\Delta G^{\neq}=19.8 \mathrm{kcal} / \mathrm{mol}\right)$. The alternative four-membered cyclic transition state $\left(\Delta G^{\ddagger}=34.6 \mathrm{kcal} / \mathrm{mol}\right)$ or the intermolecular acetate-assisted $\mathrm{C}-\mathrm{H}$ activation $\left(\Delta G^{\ddagger}=51.2\right.$ $\mathrm{kcal} / \mathrm{mol}$ ) would require much higher energy barriers. ${ }^{24,32}$ The resulting Int2a undergoes dissociative ligand exchange with bromoacetylene $\mathbf{1 b}$ through Int3a (not shown) ${ }^{24}$ to form the $\left(\eta^{2}\right.$-alkyne)rhodium complex Int4a. Subsequent alkyne insertion $\left(\Delta G^{\ddagger}=11.2 \mathrm{kcal} / \mathrm{mol}\right)$ to give Int5a, followed by AgOAc-assisted bromide elimination $\left(\Delta G^{\ddagger}=2.3 \mathrm{kcal} / \mathrm{mol}\right)$ leads to Int7a and then Int8a. The catalytic cycle restarts upon ligand exchange, delivering the final alkynylated product $3 \mathrm{ab}$ and regenerating Int1a.

Analysis of the Mulliken atomic charges in Int1a, $\mathbf{T S}_{\mathbf{1 - 2}} \mathbf{a}$, and Int $2 \mathrm{a}^{24}$ shows that the process involves an ambiphilic metal ligand activation. ${ }^{32 \mathrm{e}}$ Both an electrophilic metal center and an intramolecular basic ligand are key for the heterolytic scission of the $\mathrm{C}-\mathrm{H}$ bond and formation of the $\mathrm{C}-\mathrm{Rh}$ bond (Figure 2). In

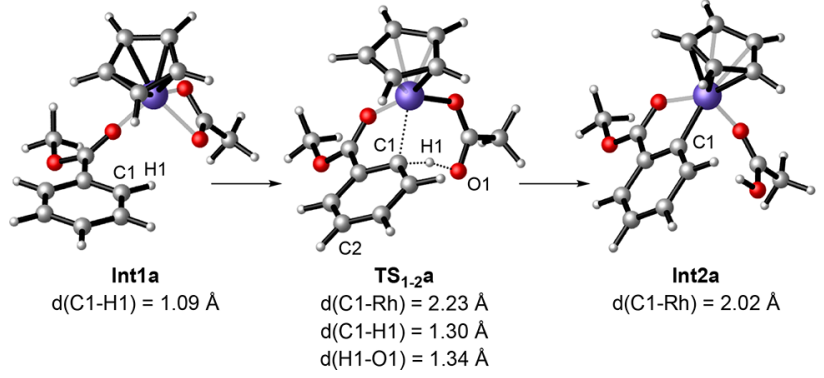

Figure 2. Calculated structures for the $\mathrm{C}-\mathrm{H}$ activation via $\mathbf{T S}_{1-2} \mathbf{a}^{24}$

$\mathrm{TS}_{1-2} \mathrm{a}$, the carbon involved in the $\mathrm{C}-\mathrm{H}$ activation shows a certain $\mathrm{sp}^{3}$ character (the $\mathrm{Rh}-\mathrm{C}-\mathrm{H}$ angle is $73.8^{\circ}$ ). ${ }^{24}$ The $\mathrm{C}-$ $\mathrm{Rh}$ distance $(2.23 \AA)$ in $\mathbf{T S}_{1-2} \mathbf{a}$ is slightly longer than that of the metallacycle Int2a $(2.02 \AA)$, whereas the $\mathrm{C}-\mathrm{H}$ distance is lengthened from $1.09 \AA$ in Int1a to $1.30 \AA$ in $\mathbf{T S}_{12} \mathbf{a}$, which suggests that the formation of the $\mathrm{Rh}-\mathrm{C}$ bond preceeds the cleavage of the $\mathrm{C}-\mathrm{H}$ bond in a concerted, but asynchronous, process.

Table 2. Substituent Effect in the Activation Energy of the $\mathrm{C}-\mathrm{H}$ Activation of Benzoates ${ }^{a}$

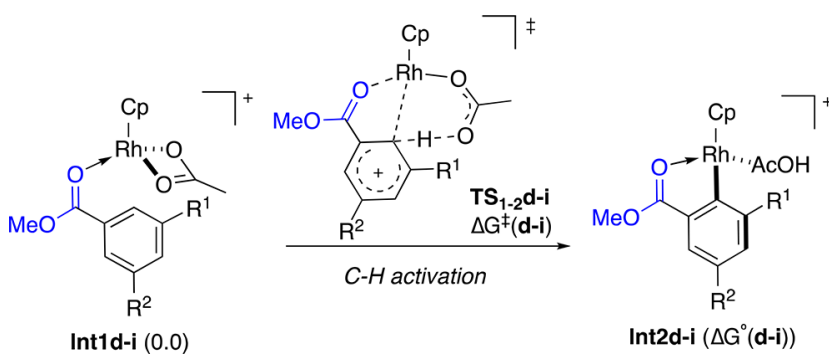

\begin{tabular}{cclcccc} 
entry & $\mathrm{R}^{1}$ & \multicolumn{1}{c}{$\mathrm{R}^{2}$} & $\mathbf{T S}_{1-2} \mathbf{d}-\mathbf{i}$ & $\Delta G^{\ddagger}(\mathbf{d}-\mathbf{i})$ & Int2d-i & $\Delta G^{\circ}(\mathbf{d}-\mathbf{i})$ \\
1 & $\mathrm{H}$ & $\mathrm{OMe}$ & $\mathbf{T S}_{1-2} \mathbf{d}$ & 17.2 & Int2d & 2.9 \\
2 & $\mathrm{H}$ & $\mathrm{Me}$ & $\mathbf{T S}_{1-2} \mathbf{e}$ & 18.9 & Int2e & 3.3 \\
3 & $\mathrm{H}$ & $\mathrm{Br}$ & $\mathbf{T S}_{1-2} \mathbf{f}$ & 20.8 & Int2f & 3.1 \\
4 & $\mathrm{H}$ & $\mathrm{CF}_{3}$ & $\mathbf{T S}_{1-2} \mathbf{g}$ & 21.5 & Int2g & 3.4 \\
5 & $\mathrm{H}$ & $\mathrm{F}$ & $\mathbf{T S}_{1-2} \mathbf{h}$ & 19.5 & Int2h & 2.5 \\
6 & $\mathrm{~F}$ & $\mathrm{H}$ & $\mathbf{T S}_{1-2} \mathbf{i}$ & 17.8 & Int2i & 2.7
\end{tabular}

${ }^{a}$ Free energies in $\mathrm{kcal} / \mathrm{mol}$.

Alternative alkynylation pathways were also considered, although they proved to be less favored. ${ }^{24}$ For instance, the oxidative addition of the $\mathrm{C}(\mathrm{sp})-\mathrm{Br}$ bond to the metal center in Int4a to form a $\mathrm{Rh}(\mathrm{V})$ intermediate ${ }^{33}$ demands a highly unlikely activation energy of $41.6 \mathrm{kcal} / \mathrm{mol}$. On the basis of the computed energies, the $\mathrm{C}-\mathrm{H}$ metalation is the ratedetermining step, which is in agreement with the experimental results. Similar energy profiles were found in the case of methyl benzyl ether 4a (Scheme 9, pathway $\mathbf{b}$ ) and acetophenone $\mathbf{6 k}$ (Scheme 9, pathway c), which means that the same reaction mechanism presumably operates for them. ${ }^{24}$ Consistent with the experimental results, among the different substrates, the C$\mathrm{H}$ functionalization of the ketones is the most energetically favored $\left(\Delta G^{\ddagger}=18.4 \mathrm{kcal} / \mathrm{mol}\right)$, whereas the corresponding to the benzyl ethers is the most energetically costly $\left(\Delta G^{\ddagger}=20.6\right.$ $\mathrm{kcal} / \mathrm{mol}$ ).

In addition, the $\mathrm{C}-\mathrm{H}$ activation step was computed for differently meta-substituted methyl benzoates to study the influence of the electronic effects on the energy barrier. Calculations showed that the more electron-rich the sub- 
stituent, the lower the activation energy results (Table 2, entries $1-4)$. This is in total agreement with the experimental results observed for meta-substituted ethyl benzoates (Figure 1) and supports an electrophilic substitution type mechanism for the formation of the five-membered-ring rhodacycle.

In the case of $m$-fluorobenzoate, the $\mathrm{C}-\mathrm{H}$ activation preferentially occurs at the ortho $\left(\Delta G^{\neq}=17.8 \mathrm{kcal} / \mathrm{mol}\right.$, Table 2, entry 6) rather than the para position $\left(\Delta G^{\ddagger}=19.5\right.$ $\mathrm{kcal} / \mathrm{mol}$, Table 2, entry 5) respect to the fluoro substituent. This $o$-fluorine effect has been experimentally observed with $m$ fluoro-substituted benzoate 3j (Scheme 2) or benzyl ether compound 5m (Scheme 3), as the metal-carbon bond strength would be increased at this position. ${ }^{34}$

\section{CONCLUSIONS}

In summary, we have found that the alkynylation of benzyl methyl ethers, aryl esters, and aryl ketones can be carried out using rhodium catalysis in a general manner. This is the first report of a broad-range $o-\mathrm{C}-\mathrm{H}$ functionalization of weakly coordinating benzyl ethers. The Rh-catalyzed alkynylation of aryl esters and aryl ketones takes place under milder conditions (45-70 ${ }^{\circ} \mathrm{C}$ for esters and $25-90{ }^{\circ} \mathrm{C}$ for ketones) in comparison to those recently reported using Ir catalysis (120 $\left.{ }^{\circ} \mathrm{C}\right)$. The alkynylation of vinyl $\mathrm{C}-\mathrm{H}$ bonds of $\alpha, \beta$-unsaturated esters and ketones is also possible using rhodium catalysis. Furthermore, other uncommon functional groups such as amine, thioether, thioacetal, sulfoxide, sulfone, phenol ester, and carbamate can also be used as directing groups for the alkynylation. Our mechanistic study shows that the alkynylation reaction proceeds by a turnover-limiting $\mathrm{C}-\mathrm{H}$ activation step via an electrophilic-type substitution, followed by insertion of the bromoalkyne and bromide elimination.

\section{ASSOCIATED CONTENT}

\section{S Supporting Information}

The Supporting Information is available free of charge on the ACS Publications website at DOI: 10.1021/acscatal.7b04395.

Additional details, experimental procedures, characterization data for compounds, and computational results (PDF)

\section{AUTHOR INFORMATION}

\section{Corresponding Author}

*E-mail for A.M.E.: aechavarren@iciq.es.

\section{ORCID 1}

Ophélie Quinonero: 0000-0003-4561-8763

M. Elena de Orbe: 0000-0001-9603-3699

Antonio M. Echavarren: 0000-0001-6808-3007

\section{Author Contributions}

${ }^{\S}$ E.T. and O.Q. contributed equally.

\section{Notes}

The authors declare no competing financial interest.

\section{ACKNOWLEDGMENTS}

We thank the Agencia Estatal de Investigación (CTQ201675960-P MINECO/AEI/FEDER, UE), Severo Ochoa Excellence Acreditation 2014-2018 (SEV-2013-0319 and Severo Ochoa predoctoral fellowship to M.E.d.O.), Juan de la Cierva postdoctoral fellowship (O.Q.), the European Research Council (Advanced Grant No. 321066), the AGAUR (2014 SGR 818), and the CERCA Program/Generalitat de Catalunya for financial support. We also thank CELLEX-ICIQ HTE laboratory.

\section{REFERENCES}

(1) (a) Acetylene Chemistry: Chemistry, Biology and Material Science; Diederich, F., Stang, P. J., Tykwinski, R. R., Eds.; Wiley-VCH: Weinheim, Germany, 2005. (b) Boyd, G. V. The Chemistry of Triple Bonded Functional Groups; Patai, S., Ed.; Wiley: Hoboken, NJ, 1994; Chapter 5.

(2) (a) Zhou, Z.-F.; Menna, M.; Cai, Y. S.; Guo, Y. W. Chem. Rev. 2015, 115, 1543-1596. (b) Chai, Q.-Y.; Yang, Z.; Lin, H. W.; Han, B. N. Mar. Drugs 2016, 14, 216.

(3) Lamberth. Bioorg. Med. Chem. 2009, 17, 4047-4063.

(4) Broggi, A.; Tomasi, I.; Bianchi, L.; Marrocchi, A.; Vaccaro, L. ChemPlusChem 2014, 79, 486-507.

(5) (a) Fürstner, A. Chem. Soc. Rev. 2009, 38, 3208-3221. (b) Shapiro, N. D.; Toste, F. D. Synlett 2010, 2010, 675-691. (c) Obradors, C.; Echavarren, A. M. Acc. Chem. Res. 2014, 47, 902912. (d) Fensterbank, L.; Malacria, M. Acc. Chem. Res. 2014, 47, 953965. (e) Dorel, R.; Echavarren, A. M. Chem. Rev. 2015, 115, 90289072. (f) Pflästerer, D.; Hashmi, A. S. K. Chem. Soc. Rev. 2016, 45, 1331-1367. (g) Echavarren, A. M.; Muratore, M. N.; López-Carrillo, V.; Escribano-Cuesta, A.; Huguet, A.; Obradors, C. Org. React. 2017, 92, 1.

(6) (a) Negishi, E.; Anastasia, L. Chem. Rev. 2003, 103, 1979-2018. (b) Doucet, H.; Hierso, J.-C. Angew. Chem., Int. Ed. 2007, 46, 834871. (c) Chinchilla, R; Nájera, C. Chem. Soc. Rev. 2011, 40, 50845121. (d) Chinchilla, R.; Nájera, C. Chem. Rev. 2014, 114, 1783-1826. (e) Wang, D.; Gao, S. Org. Chem. Front. 2014, 1, 556-566.

(7) For reviews on $\mathrm{C}\left(\mathrm{sp}^{2}\right)-\mathrm{H}$ alkynylation, see: (a) Colby, D. A.; Bergman, R. G.; Ellman, J. A. Chem. Rev. 2010, 110, 624-655. (b) Dudnik, A. S.; Gevorgyan, V. Angew. Chem., Int. Ed. 2010, 49, 2096-2098. (c) Chen, Z.; Wang, B.; Zhang, J.; Yu, W.; Liu, Z.; Zhang, Y. Org. Chem. Front. 2015, 2, 1107-1295. For a review on EBX, see: (d) Waser, J. Synlett 2016, 27, 2761-2773. For more works in the field of $\mathrm{C}\left(\mathrm{sp}^{2}\right)-\mathrm{H}$ alkynylation, see: (e) Kim, S. H.; Yoon, J.; Chang, S. Org. Lett. 2011, 13, 1474-1477. (f) Feng, C.; Feng, D.; Luo, Y.; Loh, T.-P. Org. Lett. 2014, 16, 5956-5959. (g) Feng, C.; Loh, T.-P. Angew. Chem., Int. Ed. 2014, 53, 2722-2726. (h) Feng, C.; Feng, D.; Loh, T.P. Chem. Commun. 2014, 50, 9865-9868. (i) Zhang, X.; Qi, Z.; Gao, J.; Li, X. Org. Biomol. Chem. 2014, 12, 9329-9332. (j) Zhang, Z.-Z.; Liu, B.; Wang, C.-Y.; Shi, B.-F. Org. Lett. 2015, 17, 4094-4097. (k) Sauermann, N.; González, M. J.; Ackermann, L. Org. Lett. 2015, 17, 5316-531. (1) Landge, V. G.; Midya, S. P.; Rana, J.; Shinde, D. R; Balaraman, E. Org. Lett. 2016, 18, 5252-5255. (m) Ye, X.; Xu, C.; Wojtas, L.; Akhmedov, N. G.; Chen, H.; Shi, X. Org. Lett. 2016, 18, 2970-2973. (n) Boobalan, R; Gandeepan, P.; Cheng, C.-H. Org. Lett. 2016, 18, 3314-3317. (o) Tang, G.-D.; Pan, C.-L.; Xie, F. Org. Biomol. Chem. 2016, 14, 2898-2904. (p) Liu, B.; Wang, X.; Ge, Z.; Li, R. Org. Biomol. Chem. 2016, 14, 2944-2949. (q) Landge, V. G.; Jaiswal, G.; Balaraman, E. Org. Lett. 2016, 18, 812-815. (r) Wang, S.-B.; Gu, Q.; You, S.-L. J. J. Org. Chem. 2017, 82, 11829-11835. (s) Székely, A.; Péter, Á.; Aradi, K.; Tolnai, G. L.; Novák, Z. Org. Lett. 2017, 19, 954957. (t) Hu, S.; Lu, L.; Zhu, T.; Wu, Q.; Chen, Y.; Li, J. J.; Zhao, J. Org. Biomol. Chem. 2018, 16, 43-47.

(8) (a) Seregin, I. V.; Ryabova, V.; Gevorgyan, V. J. Am. Chem. Soc. 2007, 129, 7742-7743. (b) Matsuyama, N.; Hirano, K.; Satoh, T.; Miura, M. Org. Lett. 2009, 11, 4156-4159. (c) Besselievre, F.; Piguel, S. Angew. Chem., Int. Ed. 2009, 48, 9553-9556. (d) Wei, Y.; Zhao, H.; Kan, J.; Su, W.; Hong, M. J. Am. Chem. Soc. 2010, 132, 2522-2523. (e) Brand, J. P.; Charpentier, J.; Waser, J. Angew. Chem., Int. Ed. 2009, $48,9346-9349$.

(9) (a) Tobisu, M.; Ano, Y.; Chatani, N. Org. Lett. 2009, 11, 32503252. (b) Collins, K. D.; Lied, F.; Glorius, F. Chem. Commun. 2014, 50, 4459-4461. (c) Xie, F.; Qi, Z.; Yu, S.; Li, X. J. Am. Chem. Soc. 2014, 136, 4780-4787. (d) Ruan, Z.; Sauermann, N.; Manoni, E.; Ackermann, L. Angew. Chem., Int. Ed. 2017, 56, 3172-3176.

(10) Gensch, T.; James, M.; Dalton, T.; Glorius, F. Angew. Chem., Int. Ed. 2017, DOI: 10.1002/anie.201710377. 
(11) Tan, E.; Konovalov, A. I.; Fernández, G. A.; Dorel, R.; Echavarren, A. M. Org. Lett. 2017, 19, 5561-5564.

(12) (a) Chen, C.; Liu, P.; Tang, J.; Deng, G.; Zeng, X. Org. Lett. 2017, 19, 2474-2477. (b) Mei, R.; Zhang, S.-K.; Ackermann, L. Org. Lett. 2017, 19, 3171-3174. (c) Chen, C.; Zeng, X. Eur. J. Org. Chem. 2017, 2017, 4749-4752.

(13) For examples of ester-directed $\mathrm{C}\left(\mathrm{sp}^{2}\right)-\mathrm{H}$ functionnalization, see: (a) Sonoda, M.; Kakiuchi, F.; Kamatani, A.; Chatani, N.; Murai, S. Chem. Lett. 1996, 25, 109-110. (b) Kawamorita, S.; Ohmiya, H.; Hara, K.; Fukuoka, A.; Sawamura, M. J. Am. Chem. Soc. 2009, 131, 50585059. (c) Kim, J.; Chang, S. Angew. Chem. 2014, 126, 2235-2239. (d) Yang, Y.; Lin, Y.; Rao, Y. Org. Lett. 2012, 14, 2874-2877. (e) Yu, W.; Zhang, W.; Liu, Z.; Zhang, Y. Chem. Commun. 2016, 52, 68376840. (f) Coxon, T. J.; Fernandez, M.; Barwick-Silk, J.; McKay, A. I.; Britton, L. E.; Weller, A.; Willis, M. C. J. Am. Chem. Soc. 2017, 139, 10142-10149.

(14) For examples of ketone-directed $\mathrm{C}\left(\mathrm{sp}^{2}\right)-\mathrm{H}$ functionnalization, see: (a) Murai, S.; Kakiuchi, F.; Sekine, S.; Tanaka, Y.; Kamatani, A.; Sonoda, M.; Chatani, N. Nature 1993, 366, 529-531. For a review, see: (b) Huang, Z.; Lim, H. N.; Mo, F.; Young, M. C.; Dong, G. Chem. Soc. Rev. 2015, 44, 7764-7786. (c) Shang, R.; Ilies, L.; Nakamura, E. J. Am. Chem. Soc. 2016, 138, 10132-10135. (d) Zhao, Y.; Li, S.; Zheng, X.; Tang, J.; She, Z.; Gao, G.; You, J. Angew. Chem., Int. Ed. 2017, 56, 4286-4289. (e) Zhang, B.; Wang, H.-W.; Kang, Y.-S.; Zhang, P.; Xu, H.-J.; Lu, Y.; Sun, W.-Y. Org. Lett. 2017, 19, 5940-5943.

(15) Engle, K. M.; Mei, T. S.; Wasa, M.; Yu, J.-Q. Acc. Chem. Res. 2012, 45, 788-802.

(16) For examples of ether-directed $\mathrm{C}-\mathrm{H}$ functionalization, see: (a) Kawamorita, S.; Ohmiya, H.; Hara, K.; Fukuoka, A.; Sawamura, M. J. Am. Chem. Soc. 2009, 131, 5058-5059. (b) Liskey, C. W.; Hartwig, J. F. J. Am. Chem. Soc. 2012, 134, 12422-12425. (c) Li, G.; Leow, D.; Wan, L.; Yu, J.-Q. Angew. Chem., Int. Ed. 2013, 52, 1245-1247.

(17) During the preparation of this paper, the ortho alkynylation of aryl ketones was reported using $\left[\mathrm{IrCp}^{*} \mathrm{Cl}_{2}\right]_{2}(4 \mathrm{~mol} \%), \operatorname{AgNTf}_{2}(16$ $\mathrm{mol} \%$ ), $\mathrm{NaOAc}\left(30 \mathrm{~mol} \%\right.$ ), and $\mathrm{AgOAc}\left(2\right.$ equiv) in DCE at $120^{\circ} \mathrm{C}$ : Li, X.; Wu, G.; Liu, X.; Zhu, Z.; Huo, Y.; Jiang, H. J. Org. Chem. 2017, $82,13003-13011$. The alkynylation of esters (six examples) and one example of alkynylation of an $\alpha, \beta$-unsaturated ketone were also reported in this study.

(18) For $N, N$-dimethylamino-directed $\mathrm{C}\left(\mathrm{sp}^{2}\right)--\mathrm{H}$ functionalization, see: (a) Kakiuchi, F.; Igi, K.; Matsumoto, M.; Hayamizu, T.; Chatani, N.; Murai, S. Chem. Lett. 2002, 31, 396-397. (b) Cai, G.; Fu, Y.; Li, Y.; Wan, X.; Shi, Z. J. Am. Chem. Soc. 2007, 129, 7666-7673. (c) Gao, D.W.; Shi, Y.-C.; Gu, Q.; Zhao, Z.- L.; You, S.-L. J. Am. Chem. Soc. 2013 $135,86-89$

(19) For thioether-directed $\mathrm{C}\left(\mathrm{sp}^{2}\right)-\mathrm{H}$ functionalization, see: (a) $\mathrm{Yu}$, M.; Xie, Y.; Xie, C.; Zhang, Y. Org. Lett. 2012, 14, 2164-2167. (b) Yao, J.; Yu, M.; Zhang, Y. Adv. Synth. Catal. 2012, 354, 32053210. (c) Xu, B.; Liu, W.; Kuang, C. Eur. J. Org. Chem. 2014, 2014, 2576-2583. (d) Villuendas, P.; Urriolabeitia, E. P. Org. Lett. 2015, 17, 3178-3181. (e) Zhang, X.-S.; Zhang, Y.-F.; Li, Z.-W.; Luo, F.-X.; Shi, Z.-J. Angew. Chem., Int. Ed. 2015, 54, 1-6.

(20) For sulfoxide-directed $\mathrm{C}\left(\mathrm{sp}^{2}\right)-\mathrm{H}$ functionalization, see: (a) Samanta, R.; Antonchick, A. P. Angew. Chem., Int. Ed. 2011, 50, 5217-5220. (b) Hazra, C. K.; Dherbassy, Q.; Wencel-Delord, J.; Colobert, F. Angew. Chem., Int. Ed. 2014, 53, 13871-13875. (c) Nobushige, K.; Hirano, K.; Satoh, T.; Miura, M. Org. Lett. 2014, 16, 46-49. (d) For a review, see: Pulis, A. P.; Procter, D. J. Angew. Chem., Int. Ed. 2016, 55, 9842.

(21) For an example of sulfone-directed $\mathrm{C}\left(\mathrm{sp}^{2}\right)-\mathrm{H}$ functionalization, see: Nobushige, K.; Hirano, K.; Satoh, T.; Miura, M. Tetrahedron 2015, 71, 6506-6512.

(22) For examples of carbamate-directed $\mathrm{C}\left(\mathrm{sp}^{2}\right)-\mathrm{H}$ functionalization, see: (a) Hoshino, Y.; Shibata, Y.; Tanaka, K. Adv. Synth. Catal. 2014, 356, 1577-1585. (b) Zhang, X.; Si, W.; Bao, M.; Asao, N.; Yamamoto, Y.; Jin, T. Org. Lett. 2014, 16, 4830-4833. (c) Morita, T.; Satoh, T.; Miura, M. Org. Lett. 2017, 19, 1800-1803.
(23) For an example of phenol ester directed $\mathrm{C}\left(\mathrm{sp}^{2}\right)-\mathrm{H}$ functionalization, see: Xiao, B.; Fu, Y.; Xu, J.; Gong, T.-J.; Dai, J.-J.; Yi, J.; Liu, L. J. Am. Chem. Soc. 2010, 132, 468-469.

(24) See the Supporting Information for additional details.

(25) Wang, J. Stereoselective Alkene Synthesis; Springer-Verlag: Berlin, Heidelberg, 2012.

(26) Simmons, E. M.; Hartwig, J. F. Angew. Chem., Int. Ed. 2012, 51, 3066-3072.

(27) Stuart, D. R.; Alsabeh, P.; Kuhn, M.; Fagnou, K. J. Am. Chem. Soc. 2010, 132, 18326-18339.

(28) Ma, W.; Mei, R.; Tenti, G.; Ackermann, L. Chem. - Eur. J. 2014, 20, 15248-15251.

(29) Hansch, C.; Leo, A.; Taft, R. W. Chem. Rev. 1991, 91, 165-195.

(30) DFT calculations were performed using the Gaussian 09 suite of programs, using wB97XD. $\mathrm{Rh}, \mathrm{Ag}$, and $\mathrm{Br}$ atoms were described by ECP with the LANL2DZ basis set. Polarization functions were added for $\mathrm{Rh}\left(\zeta_{\mathrm{f}}=1.35\right), \mathrm{Ag}\left(\zeta_{\mathrm{f}}=1.611\right)$ and $\mathrm{Br}\left(\zeta_{\mathrm{d}}=0.428\right)$. The 6-31G(d) basis set was employed for all remaining atoms. Full geometry optimizations were carried out in 1,2-dichloroethane, through an implicit solvent SMD. ${ }^{24}$

(31) Sperger, T.; Sanhueza, I. A.; Kalvet, I.; Schoenebeck, F. Chem. Rev. 2015, 115, 9532-9586.

(32) Selected discussions of $\mathrm{C}-\mathrm{H}$ activation mechanisms: (a) Qi, X.; Li, Y.; Bai, R.; Lan, Y. Acc. Chem. Res. 2017, 50, 2799-2808. (b) Roudesly, F.; Oble, J.; Poli, G. J. Mol. Catal. A: Chem. 2017, 426, 275-296. (c) Ackermann, L. Chem. Rev. 2011, 111, 1315-1345. (d) Lapointe, D.; Fagnou, K. Chem. Lett. 2010, 39, 1118-1126. (e) Boutadla, Y.; Davies, D. L.; Macgregor, S. A.; PobladorBahamonde, A. I. Dalton Trans. 2009, 5820-5831. (f) Gorelsky, S. I.; Lapointe, D.; Fagnou, K. J. Am. Chem. Soc. 2008, 130, 1084810849. (g) Oxgaard, J.; Tenn, W. J., III; Nielsen, R. J.; Periana, R. A.; Goddard, W. A., III Organometallics 2007, 26, 1565-1567. (h) GarcíaCuadrado, D.; de Mendoza, P.; Braga, A. A. C.; Maseras, F.; Echavarren, A. M. J. Am. Chem. Soc. 2007, 129, 6880-6886. (i) Li, L.; Brennessel, W. W.; Jones, W. D. Organometallics 2009, 28, 34923500.

(33) Vásquez-Céspedes, S.; Wang, X.; Glorius, F. ACS Catal. 2018, 8, $242-257$.

(34) (a) Clot, E.; Mégret, C.; Eisenstein, O.; Perutz, R. N. J. Am. Chem. Soc. 2009, 131, 7817-7827. (b) Evans, M. E.; Burke, C. L.; Yaibuathes, S.; Clot, E.; Eisenstein, O.; Jones, W. D. J. Am. Chem. Soc. 2009, 131, 13464-13473. (c) Clot, E.; Besora, M.; Maseras, F.; Mégret, C.; Eisenstein, O.; Oelckers, B.; Perutz, R. B. Chem. Commun. 2003, 490-491. 